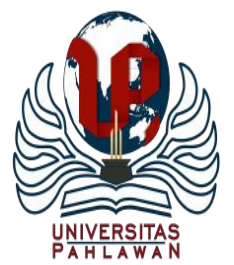

Edukatif : Jurnal Ilmu Pendidikan Volume 3 Nomor 5 Tahun 2021 Halm 1918 - 1927

EDUKATIF: JURNAL ILMU PENDIDIKAN

Research \& Learning in Education

https:/ledukatif.org/index.php/edukatif/index

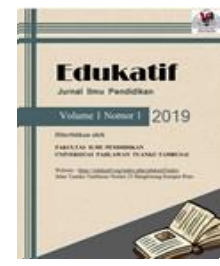

\title{
Kepemimpinan Buya Marwan Alwi Tuangku Lubuak Ameh, Pengembangan Organisasi, Team Building dan Prilaku Inovatif
}

\author{
Ridha Albiy ${ }^{1 凶}$, Muhammad Suhardi ${ }^{2}$, Rusdinal $^{3}$, Nurhizrah Gistituati ${ }^{4}$ \\ Universitas Negeri Padang, Indonesia ${ }^{1,2,3,4}$ \\ E-mail : ridha.albiy.1979@gmail.com ${ }^{1}$, aji.azella@gamail.com² ${ }^{2}, \underline{\text { rusdinal @ fip.unp.ac.id }}^{3}$, \\ gistituatinurhizrah@gmail.com ${ }^{4}$
}

\begin{abstract}
Abstrak
Lembaga pendidikan pesantren sangat unik untuk dilakukan sebuah penelitian, sebab Buya selaku pemimpin pondok pesantren mempunyai tugas dan fungsi bukan sekedar memimpin pesantren, namun juga harus mampu mengembangkan organisasinya. Penelitian ini bertujuan untuk menggambarkan bagaimana kepemimpinan Buya Marwan Alwi Tuangku Lubuk Ameh dalam mendirikan, dan mengembangkan Pondok Pesantren Darul Makmur dilihat dari 3 aspek yaitu pengembangan organisasi, proses pembentukan team building dan proses penumbuhan prilaku inovatif. Penelitian ini menggunakan metode kualitatif dengan pendekatan studi tokoh. Proses pengumpulan data dilakukan melalui wawancara, dokumentasi, dan observasi, analisis data menggunakan model Spradley yang terdiri dari 4 cara, yaitu: 1.) Analisis domain; 2.) Analisis taksonomi; 3.) Analisis komponensial; dan 4.) Analisis tema kultural. Dari hasil penelitian ini dapat diperoleh data, yaitu: 1.) Proses pengembangan organisasi dilakukan dengan cara memotivasi dan menginspirasi anggota bawahannya agar memiliki semangat yang tinggi dalam mengembangkan pondok pesantren; 2.) Proses pembentukan team building lebih banyak dilakukan melalui interaksi pola pikir; dan 3.) Proses menumbuhkan perilaku inovatif menggunakan cara dengan pendelegasian tugas-tugas.
\end{abstract}

Kata Kunci: Kepemimpinan, Pengembangan organisasi, team building dan prilaku inofatif.

\begin{abstract}
Pesantren educational institutions are very unique to do a research, because Buya as the leader of the Islamic boarding school has the duties and functions not only to lead the pesantren, but also to be able to develop the organization. This study aims to describe how the leadership of Buya Marwan Alwi Tuangku Lubuk Ameh in establishing and developing the Darul Makmur Islamic Boarding School was seen from 3 aspects, namely organizational development, the process of team building and the process of growing innovative behavior. This study uses a qualitative method with a character study approach. The process of collecting data is done through interviews, documentation, and observation, data analysis using the Spradley model which consists of 4 ways, namely: 1.) Domain analysis; 2.) Taxonomic analysis; 3.) Componential analysis; and 4.) Analysis of cultural themes. From the results of this study, data can be obtained, namely: 1.) The process of organizational development is carried out by motivating and inspiring subordinate members to have high enthusiasm in developing Islamic boarding schools; 2.) The process of forming team building is mostly done through the interaction of mindsets; and 3.) The process of fostering innovative behavior using a way of delegating tasks.
\end{abstract}

Keywords: Leadership, Organizational development, team building and behavior.

Copyright (c) 20212021 Ridha Albiy, Muhammad Suhardi, Rusdinal, Nurhizrah Gistituati

$\triangle$ Corresponding author

Email : ridha.albiy.1979@gmail.com

DOI : https://doi.org/10.31004/edukatif.v3i5.691 
1919 Kepemimpinan Buya Marwan Alwi Tuangku Lubuak Ameh, Pengembangan Organisasi, Team Building dan Prilaku Inovatif - Ridha Albiy, Muhammad Suhardi, Rusdinal, Nurhizrah Gistituati

DOI: https://doi.org/10.31004/edukatif.v3i5.691

\section{PENDAHULUAN}

Kepemimpinan adalah suatu proses yang dilukiskan dimana seseorang pimpinan akan memberikan perintah atau pengaruh, bimbingan atau proses yang bertujuan untuk mempengaruhi pekerjaan yang dilakukan orang lain dalam rangka mencapai atau memilih tujuan yang telah di tetapkan. Pemimpin adalah pusat pencapaian organisasi (Solomon \& Steyn, 2017). Pemimpin adalah individu yang menetapkan arah untuk kelompok kerja individu dan yang mendapatkan komitmen dari kelompok anggota untuk menetapkan arah dan yang kemudian memotivasi anggota untuk mencapai hasil sesuai dengan arahannya (Banutu-Gomez \& Banutu-Gomez, 2016). Sekaitan dengan itu manusia dilahirkan di muka bumi mempunyai tugas untuk menggali berbagai potensi kepemimpinannya dalam rangka berpartisipasi dalam pemberian pelayanan serta pengabdian yang diniatkan semata-mata karena Allah SWT. Cara tepat untuk mewujudkan hal tersebut adalah dengan menjalankan perannya sebagai pembawa rahmat bagi bagi alam semesta (rahmatan lilalmiin).

Buya/Syekh dalam kosa-kata Jawa disebut kiai. Gelar buya/Syekh dipakai untuk tiga jenis yang berbeda. Sebagai gelar kehormatan bagi barang-barang yang dianggap keramat, misalnya "Syekh Sulaiman arRasuli”, sebutan kehormatan terhadap pimpinan Madrasah Tarbiyah Islamiyah Candung Bukittinggi. Sebagai gelar kehormatan untuk orang tua pada umumnya. Umumnya gelar buya dilekatkan pada seorang ahli agama Islam yang memiliki atau menjadi pemimpin madrasah, dan mengajar kitab-kitab klasik. Selain itu gelar buya juga dipakai untuk sebutan orang yang alim (orang yang sangat luas pengetahuan keagamaanya. (Zein \& Salam, 2019).

Sedangkan menurut undang-undang No 18 Tahun 2019 tentang Pensantren menjelas pada pasal 1 butir 9 bahwa Kiai, Tuan Guru, Anre Gurutta, Inyiak, Syekh, Ajengan, Buya, Nyai, atau sebutan lain yang selanjutnya disebut Kiai adalah seorang pendidik yang memiliki kompetensi ilmu agama Islam yang berperan sebagai figur, teladan, dan/atau pengasuh Pesantren. Kemudian pada pasal 9 ayat 2 dijelaskan juga bahwa Kiai sebagai mana yang dimaksud pada ayat (1) merupakan pemimpin tertinggi Pesantren yang mampu menjadi pengasuh, figure dan teladan dalam penyelenggaraan Pesantren.

Pondok pesantren yang masih mempertahankan sistem pendidikan tradisional, maupun yang sudah merubah pola pendidikannya kearah yang modern sampai saat ini keberadaanya sangat memberi pengaruh yang besar terhadap kehidupan masyarakat Indonesia (Siswanto, 2015). Oleh sebab itu, keberadaan sosok Buya sebagai seorang Rais Alam di lingkungan pondok pesantren menjadi bagian dari khazanah keilmuan yang mempunyai daya tarik tersendiri untuk selalu di kaji dari berbagai sisi. Kedudukan Buya menjadi hal terpenting dalam sebuah lembaga pesantren. Karana kapasitas Buya tersebut bisa sebagai perancang (arsitektur), pendiri dan pengembang (developer), dan juga sebagai seorang pemimpin dan pengelola (leader dan manager) sebuah pesantren yang beliau kelola (Kediri \& Jombang, n.d.). Bahkan, kalau dilihat dari tugas dan perannya kepemimpinan seorang buya sangatlah komplek yaitu sebagai pelopor dan penggerak seluruh aktivitas yang ada dipesantren, tenaga pendidik dan juga berperan aktif dalam mengatasi berbagai permasalahan social yang terjadi dalam masyarakat (Zamakhsyarie, 2011).

Setiap pondok pesantren Buya merupakan figure sentral. Figur sentral seorang Buya bukan saja disebabkan karena keilmuannya, melainkan juga karena Buya lah yang menjadi penggagas, pemilik dan pewakaf pesantren itu sendiri. Perjuangan Buya tidak terbatas pada ilmu, tenaga, waktu tetapi juga tanah dan materi lainnya diberikan demi kemajuan syiar Islam (Suharto, 2011). Disamping itu, keberadaan Buya di memiliki kharismatik yang tinggi dimata masyarakat, serta keberadaan Buya tidak boleh diganggu gugat dan juga menjadi variable penentu ketahanan pesantren. Pada posisnya tersebut buya juga bisa disebut sebagai agent of change dalam masyarakat dan memiliki peran yang penting dalam perubahan social. Beranjak dari teori diatas diambil kesimpulan bahwa Buya memiliki peran yang kuat terhadap ketahanan pesantren, selain itu mengakomodir terhadap perubahan-perubahan yang terjadi dalam pesantren. Disamping itu pesantren juga 
1920 Kepemimpinan Buya Marwan Alwi Tuangku Lubuak Ameh, Pengembangan Organisasi, Team Building dan Prilaku Inovatif - Ridha Albiy, Muhammad Suhardi, Rusdinal, Nurhizrah Gistituati

DOI: https://doi.org/10.31004/edukatif.v3i5.691

memiliki keterkaitan dengan komunitas lingkungannya serta posisi kharismatik Buya sebagai pemimpin pesantren (Anwar, 2011).

Kepemimpinan mempunyai hubungan yang erat dengan sistem sosial kelompok maupun individu. Dalam rangka meciptakan kepemimpinan yang efektif, maka kepemimpinan harus dijalankan sesuai dengan fungsinya. Wirawan (2013) dalam bukunya kepemimpinan teori, psikologi, perilaku organi sasi, aplikasi dan penelitian menyatakan beberapa fungsi kepemimpinan sebagai berikut: 1.) Menciptakan visi; 2.) Mengembangkan budaya organisai; 3.) Menciptakan sinergis; 4.) Menciptakan perubahan; 5.) Memotivasi para pengikut; 6.) Memberdayakan pengikut; 7.) Mewakili sistem sosial; 8.) Manajer konflik; dan 9.) Memberlajarkan organisasi (Wirawan, 2013).

Di dalam perkembangannya, memang pondok pesantren tidaklah semata-mata kemudian tumbuh secara stagnan dalam artian selalu berada atas pola lama yang bersifat tradisional, melainkan bisa dilakukan suatu inovasi dalam pengembangan lembaga pondok pesantren tersebut. Modernisasi yang dalam bentuk umum Indonesia lebih dikenal dengan istilah pengembangan (development) yaitu sebuah proses multidimensional yang komplek. Dalam lapangan pendidikan, modernisasi setidaknya dapat dilihat dengan direalisasikannya pembentukan lembaga-lembaga pendidikan modern yang mengadopsi dari sistem dan kelembagaan kolonial Belanda, bukan dari sistem pendidikan Islam tradisional (Baharun, 2013). Meskipun belum terdapat kesepakatan bulat tentang tipologi kepemimpinan yang secara luas, dewasa ini dikenal lima tipe kepemimpinan yang diakui keberadaannya, yaitu: 1.) Tipe otokratik; 2.) Tipe paternalistik; 3.) Tipe kharismatik yang terbagi menjadi tipe Laissez Faire dan tipe demokratik; 4.) Tipe kepemimpinan transformasional yang dikembangkan oleh Benard M. Bass; dan 5.) Tipe kepemimpinan transaksional yang dikembangkan oleh James MacGregor Burns (Siagian, 2010).

Secara konseptual, kepemimpinan transformasional didefinisikan sebagai kemampuan pemimpin mengubah lingkungan kerja, motivasi kerja, dan pola kerja, nilai-nilai kerja yang dipersepsikan bawahan, sehingga mereka lebih mampu mengoptimalkan kinerja untuk mencapai tujuan organisasi. Pemimpin juga mentransformasikan harapan untuk suksesnya pengikut, serta nilai-nilai, dan mengembangkan budaya organisasi untuk mencapai tujuan yang ditetapkan pemimpin. Melalui kepemimpinan transformasional pengikut dapat mencapai kinerja yang melebihi yang telah diharapkan pemimpin (performance beyond expetation) (Wirawan, 2013). Menurut pandangan Bass dalam (Ancok, 2012), terdapat empat hal yang menjadi ciri pemimpin transformasional, yaitu: 1.) Pengaruh yang diidealkan (idealized influence), yaitu sifatsifat yang dikagumi pengikut dari pemimpinnya. Perwujudan sifat keteladanan antara lain adalah memberi contoh bagaimana dia berperilaku dalam melayani orang lain, khususnya dalam melayani karyawan sebagai mitra kerjanya.; 2.) Stimulasi intelektual (intellectual stimulation), yaitu proses merangsang pemikiran kreatif dan gagasan inovatif dalam diri pengikut; 3.) Kepedulian secara perorangan adalah ciri pemimpin yang memperhatikan kebutuhan karyawannya dan membantu karyawan agar mereka bisa maju dan berkembang dalam karir dan kehidupan mereka; dan 4.) Motivasi yang inspiratif adalah sifat pemimpin yang memberikan inspirasi dalam bekerja, mengajak karyawan untuk mewujudkan sebuah cita-cita bersama agar hidup dan karya mereka menjadi bermakna.

Buya Marwan Alwi Tuangku Lubuk Ameh adalah salah seorang penggas untuk berdirinya Pondok Pesantren Darul Makmur Sungai Cubadak pada tahun 2009 bersama dengan beberapa orang pengurus Masjid Makmur. Inisiatif yang beliau lakukan itulah sehingga menjadikan beliau seorang pemimpin. Dalam posisi beliau sebagai seorang pemimpin di Pondok Pesantren Darul Makmur Sungai Cubadak beliau harus memberikan visi, haluan kepada orang lain untuk melakukan pembangunan pondok pesantren.

Pembangunan dilaksanakan pada tahun 2009 dan resmi di mulai proses pembelajaran pada bulan Juli 2012 dengan 1 rombongan belajar. Pada perkembangan selanjutnya Pondok Pesantren Darul Makmur pada tahun 2020 atau pada tahun ke 8 semenjak berdiri sudah memiliki 10 rombongan belajar pada tingkat madrasah tsanawiyah dan 4 rombongan belajar di tingkat madrasah Aliyah. Proses pembelajaran di pusatkan 
1921 Kepemimpinan Buya Marwan Alwi Tuangku Lubuak Ameh, Pengembangan Organisasi, Team Building dan Prilaku Inovatif - Ridha Albiy, Muhammad Suhardi, Rusdinal, Nurhizrah Gistituati

DOI: https://doi.org/10.31004/edukatif.v3i5.691

pada 2 kampus yaitu kampus 1 yang merangkap kantor pimpinan, ruangan belajar dan asrama, serta kampus 2 untuk ruangan belajar serta ruang transit majelis guru.

Dalam beberapa literatur ditemukan berbagai model kepimpinan yang dilakukan kiai atau buya dalam pengembangan organisasi pesantrenya. Kepemimpinan Buya Marwan Alwi Tuangku Lubuk Ameh dalam mendirikan dan mengembangkan pondok pesantren menunjukkan bahwa di era globalisasi saat ini, pondok pesantren menjadi tujuan dan pilihan utama dalam dunia pendidikan. Seiring dengan hal tersebut diatas pondok pesantren juga harus menghadapi perubahan seiring dengan perkembangan akan kebutuhan masyarakat, dan tentunya fenomena tersebut menuntut adanya peran Buya sebagai seorang pemimpin pondok pesantren harus bisa menjadi agent of change sekaligus dituntut sebagai keeping a cultural life (memilihara kehidupan budaya) agar tidak kehilangan karakter kelembagaannya. Dari konteks penelitian tersebut dapat disimpulkan bahwa buya sebagai pemimpin pondok pesantren sangat dibutuhkan dan menjadi pucuk penyebab keberhasilan maupun kegagalan suatu organisasi. Dalam hal ini Buya Marwan Alwi Tuangku Lubuk Ameh sebagai seorang Buya tidak hanya menggunakan gaya kepemimpinan kharismatik saja tetapi juga menggunakan gaya kepemimpinan demokratis dan transformasionalisme yang dilakukan melalui tiga pendekatan, yaitu pengembangan organisasi, team building, dan perilaku inovatif. Oleh sebab itu penelitian ini bertujuan untuk melihat bagaimana upayab yang dilakukan oleh Buya Marwan Alwi Tuangku Lubuk Ameh dalam mengembangkan Pondok Pesantren Darul Makmur.

\section{METODE PENELITIAN}

Penelitian yang dilakukan ini merupakan suatu penelitian yang dapat dikategorikan sebagai sebuah penelitian kualitatif, karena dalam penelitian ini terfokus pada memahami tingkah laku partisipan, menggambarkan latar, menggambarkan interaksi yang kompleks, dan menggambarkan fenomena yang terjadi. Dalam implementasinya, penelitian ini dilakukan dengan menggunakan pendekatan biografi atau studi tokoh, dengan alasan antara lain: 1.) Karena peneliti memfokuskan diri pada satu orang individu, membangun penelitian dari cerita dan kejadian-kejadian spesial kemudian menempatkannya dalam konteks yang lebih luas, serta membangkitkan keberadaan peneliti dalam penelitian tersebut (Ghoni, 2012); 2.) Karena biografi atau studi tokoh merupakan studi terhadap seseorang atau individu untuk memahami perilaku dan pola interaksi manusia dengan lingkungannya melalui proses kepemimpinannya atas keinginan peneliti sendiri.

Dalam pelaksanaannya, yang menjadi fokus penelitian adalah kehidupan secara keseluruhan atau kehidupan hanya dalam beberapa fase dari seorang individu yang dianggap unik khas, menarik, atau dianggap luar biasa, sehingga layak untuk diangkat menjadi suatu penelitian dengan pendekatan kualitatif. Oleh sebab itu, peneliti mencoba untuk menemukan data serta informasi selengkap mungkin berkaitan kepemimpinan Buya Marwan Alwi Tuangku Lubuk Ameh, sehingga data yang di kumpulkan tidak terbatas hanya pada komunitas di pondok pesantren saja tetapi juga komunitas yang ada di luar pondok pesantren. Dalam penelitian kualitatif dengan menggunakan pendekatan studi tokoh ini pada umumnya menggunakan tiga metode pengumpulan data, yaitu wawancara, dokumentasi, dan observasi.

Dalam pengumpulan data penunjang penelitian peneliti terjun langsung melakukan wawancara dengan Buya Marwan Alwi Tuangku Lubuk Ameh yang berlokasi di Jorong Sungai Cubadak, Nagari Tabek Panjang Kecamatan Baso Kabupaten Agam Sumatera Barat. Penelitian ini dilaksanakan dalam kurun waktu 2 bulan. Dalam penelitian ini peneliti berupaya menggali informasi sedalam-dalamnya berkaitan dengan proses kepemimpinan beliau di pesantren. Kemudian peneliti juga mengumpulkan data melaui pribadi-probadi yang terkait dengan Buya. Diantaranya adalah Yayasan, Pimpinan Pondok Pesantren, wakil pimpinan serta beberapa orang guru dan beberapa orang santri yang menajdi asuhan Buya. Adapun proses analisis data, peneliti menggunakan model analisis data yang digagas oleh Spradley yang terdiri dari 4 cara, yaitu: 1.) Analisis domain; 2.) Analisis taksonomi; 3.) Analisis komponensial; dan 4.) Analisis tema kultural. Uji 
1922 Kepemimpinan Buya Marwan Alwi Tuangku Lubuak Ameh, Pengembangan Organisasi, Team Building dan Prilaku Inovatif - Ridha Albiy, Muhammad Suhardi, Rusdinal, Nurhizrah Gistituati

DOI: https://doi.org/10.31004/edukatif.v3i5.691

keabsahan data dalam penelitian kualitatif meliputi uji credibility (validitas internal), transferability (validitas eksternal), dependability (reliabilitas) dan confirmability (obyektivitas) (Wijaya, 2014).

\section{HASIL DAN PEMBAHASAN PENELITIAN}

Buya di dalam dunia pesantren mempunyai peran sebagai motor atau penggerak dalam membangun, mengemban dan mengembangkan pesantren. Buya bukan hanya pemimpin pondok pesantren tetapi juga pemilik pondok pesantren. Dengan demikian kemajuan dan kemunduran pondok pesantren benar-benar terletak pada kemampuan kiai dalam mengatur pelaksanaan pendidikan di dalam pesantren. Hal ini disebabkan karena besarnya pengaruh seorang kiai dan juga tidak hanya terbatas dalam pesantrennya, melainkan juga terhadap lingkungan masyarakatnya (Ghazali, 2002). Proses transformasi sosio-kultural yang berlangsung dewasa ini hampir menjamah ke setiap sudut kehidupan masyarakat. Pondok pesantren yang sering disebut-sebut sebagai lembaga pendidikan tertua yang menjaga nilai-nilai tradisionalnya pun tidak lepas dari jangkauan proses tersebut. Meski demikian pondok pesantren mampu mengembangkan organisasinya agar tetap bertahan atau survive di perkembangan zaman yang semakin besar tuntutannya ini. Keberhasilan pondok pesantren dalam perjalanan transformasi sosio-kultural yang dilaluinya tidak lepas dari peran kepemimpinan kiai di dalamnya.

Selain melakukan pendekatan pengembangan organisasi, kiai sebagai pemimpin pesantren dalam menggerakkan semua komunitas yang ada di pondok pesantren memakai pendekatan team building. Hal ini tampak dalam interaksi baik antara buya, ustadz atau ustadzah maupun para santri. Dalam memimpin Pondok Pesantren Darul Makmur Sungai Cubadak, Buya Marwan Alwi Tuangku Lubuk Ameh senantiasa berusaha untuk menyeimbangkan interaksi antara buya dengan komunitas pondok pesantrennya, baik komunitas internal (santri dan guru atau asatidz) maupun komunitas eksternal (masyarakat), melalui interaksi fisik, interaksi pola pikir, dan interaksi ruh atau batin. Dengan demikian baik para santri, guru atau asatidz, staf maupun masyarakat, dapat ikut berperan aktif serta dalam mengembangkan pondok pesantren sebagai pelaku perubahan (agent of change) dalam berbagai aspek kehidupan.

Adanya team building antara pimpinan dan bawahan merupakan salah satu bagian penting bagi setiap organisasi, termasuk organisasi yang ada di pondok pesantren. Walaupun pimpinan pondok pesantren adalah seorang buya, namun bukan berarti harus menutup diri dengan bawahannya, sebaliknya buya harus sering melakukan interaksi tidak hanya dengan komunitas internal pondok pesantren saja, namun dengan komunitas eksternal pondok pesantren juga perlu dilakukan. Hal itu senada dengan teori interaksi (interaction theory) yang pada prinsipnya sama dengan kontingensi (contingency theory) dari Fiedler dan expectancyreinforcement theory dari Stogdill (Saefullah, 2012). Dimana teori interaksi ini berasumsi bahwa semakin sering terjadi interaksi dan partisipasi dalam kegiatan bersama, semakin meningkat pula perasaan saling menyenangi satu sama lain dan saling memperjelas pengertian atas norma kelompok (Saefullah, 2012).

Interaksi fisik yang dilakukan oleh Buya Marwan Alwi Tuangku Lubuk Ameh terhadap santri akan memunculkan sikap tawaddu santri terhadap kiai dan memunculkan istilah mengharapa barokah yang artinya santri akan menuruti apa saja yang dikatakan dan diperintahkan oleh Buya Marwan Alwi Tuangku Lubuk Ameh guna mengharap barakah ilmu yang dipelajarinya di pondok pesantren. Sedangkan interaksi pola pikir yang dilakukan oleh Buya Marwan Alwi Tuangku Lubuk Ameh terhadap anggota bawahannya, juga interaksi ruh yang dilakukannya kepada masyarakat akan memunculkan sikap ketaatan, kesetian, dan kepatuhan (loyalitas) yang tinggi dari anggota bawahan maupun masyarakat terhadap buya dan pondok pesantren. Hal itu senada dengan gaya kepemimpinan tradisional yang dipaparkan oleh Weber bahwa dalam kepemimpinan tradisional, kepatuhan diberikan kepada orang atau pemimpin yang menduduki kekuasaan tradisional yang terikat pula dalam suasana tersebut. Pengikut patuh pada pimpinan tidak didasarkan pada tatanan impersonal, tetapi menjadi loyalitas pribadi dalam ruang lingkup dengan membiasakan tunduk pada kewajiban. 
1923 Kepemimpinan Buya Marwan Alwi Tuangku Lubuak Ameh, Pengembangan Organisasi, Team Building dan Prilaku Inovatif - Ridha Albiy, Muhammad Suhardi, Rusdinal, Nurhizrah Gistituati

DOI: https://doi.org/10.31004/edukatif.v3i5.691

Dari kedua pendekatan tersebut, salah satu langkah yang penting untuk melaksanakan perubahan ialah dengan memperkuat perilaku inovatif kepada anggota, kelompok dan organisasi itu sendiri. Begitu pula dengan pemberian imbalan (reward) memberi motivasi dan reinformasi (penegakan kebijaksanaan), sehingga terdapat nuansa ganda, yaitu: kebanggaan, semangat kerja, dan tanggung jawab juga merupakan langkah yang penting dalam mewujudkan perilaku inovatif. Sebagai seorang pemimpin pondok pesantren, Buya Marwan Alwi Tuangku Lubuk Ameh mengemban amanah yang besar dalam mengelola pondok pesantren. Namun hal itu bukan berarti Buya Marwan Alwi Tuangku Lubuk Ameh adalah satu-satunya orang yang menentukan arah kebijakan dan pengembangan pondok pesantren.

Manajemen di Pondok Pesantren Darul Makmur Sungai Cubadak hampir semuanya dikendalikan oleh para pengurus atau anggota bawahannya (pimpinan pondok, kepala madrasah, guru dan staf), sehingga dalam proses pengelolaan pondok dapat memunculkan perilaku inovatif para bawahannya baik itu bersifat manajerial maupun non manajerial. Perilaku inovatif yang bersifat manajerial artinya, perilaku inovatif yang terkait dengan urusan kelembagaan, sedangkan perilaku inovatif non manajerial yaitu perilaku inovatif yang tidak terkait dengan urusan kelembagaan. Perilaku inovatif yang demikian dilakukan oleh Buya Marwan Alwi Tuangku Lubuk Ameh dalam rangka ingin mengembangkan potensi bawahannya dengan tetap menjaga otoritasnya sebagai pemimpin pondok pesantren.

\section{Pengembangan Organisasi di Pondok Pesantren darul Makmur Sungai Cubadak}

Pengembangan organisasi adalah sebuah sistem aplikasi luas dan transfer pengetahuan ilmu perilaku ke rencana pengembangan, peningkatan, penguatan strategi, struktur, dan proses yang mengarah pada efektifitas organisasi (Cummings, 2014). Definisi ini secara jelas menekankan bahwa tujuan akhir dari pengembangan organisasi adalah terwujudnya efektivitas organisasi. Pada dasarnya pengembangan organisasi penting untuk dilakukan karena mengarah pada peningkatan efektifitas organisasi dengan tujuan mengupayakan perbaikan kemampuan organisasi dalam menyesuaikan diri terhadap perubahan lingkungan serta perubahan perilaku anggota organisasi (Robbins, Stephen P, 2014). Oleh karena itu, Buya Marwan Alwi Tuangku Lubuk Ameh sebagai pemimpin di Pondok Pesantren Darul Makmur bekerja sama dengan kepala pondok dan kepala madrasah melakukan perubahan yang terencana untuk keseluruhan perangkat maupun sistem, struktur, budaya, dinamika kelompok, kualitas SDM, strategi pemasaran, dan lain sebagainya agar pondok pesantren yang dipimpinnya dapat menjadi organisasi yang efektif. Adanya sosok buya sebagai pemimpin pondok pesantren menjadi salah satu faktor yang sangat menentukan kesuksesan pondok pesantren.

Dalam melakukan pengembangan organisasi Buya Marwan Alwi Tuangku Lubuk Ameh melakukan beberapa perilaku, yaitu: Pertama, Buya Marwan Alwi Tuangku Lubuk Ameh mampu menjadikan dirinya sebagai sosok pemimpin yang ideal di mata para bawahan melalui kharisma yang dimilikinya. Kharisma tersebut terlihat dari segi keilmuan yang dimiliki oleh Buya Marwan Alwi Tuangku Lubuk Ameh, baik ilmu natural maupun supranatural. Selain itu sebagai seorang pemimpin Buya Marwan Alwi Tuangku Lubuk Ameh memiliki ide besar, yakni melakukan pengembangan pendidikan pesantren, yang didorong oleh keyakinan dan niat kuat dalam mewujudkanya, serta komitmen dan konsisten dalam proses pelaksanaannya. Kedua, sebagai seorang pimpinan pondok pesantren, Buya Marwan Alwi Tuangku Lubuk Ameh piawai dalam memotivasi dan menginspirasi anggota bawahannya untuk memiliki semangat yang tinggi dalam mengembang kan pondok pesantren. Beberapa strategi yang dilakukan oleh Buya Marwan Alwi Tuangku Lubuk Ameh, antara lain: 1.) Menjadikan dirinya sebagai uswatun hasanah atau teladan yang baik bagi para bawahannya; 2.) Memberikan reward atau penghargaan bagi anggota bawahannya yang melakukan pekerjaan dengan baik; 3.) Selalu mengadakan muhasabah bersama setiap bulan dalam rangka menuju perubahan dan perbaikan serta menjadi salah satu media komunikasi Buya Marwan Alwi Tuangku Lubuk Ameh dengan semua anggota bawahannya. 
1924 Kepemimpinan Buya Marwan Alwi Tuangku Lubuak Ameh, Pengembangan Organisasi, Team Building dan Prilaku Inovatif - Ridha Albiy, Muhammad Suhardi, Rusdinal, Nurhizrah Gistituati

DOI: https://doi.org/10.31004/edukatif.v3i5.691

Ketiga, meskipun Buya Marwan Alwi Tuangku Lubuk Ameh merupakan bagian dari pendiri Pondok Pesantren Darul Makmur Sungai Cubadak, namun tidak menjadikan dirinya sebagai seorang pemimpin tunggal yang otoriter terhadap bawahannya. Menginginkan suasana organisasi yang demokratis, Buya Marwan Alwi Tuangku Lubuk Ameh pun memberikan kewenangan yang ada pada dirinya kepada semua anggota bawahan melalui cara pendelegasian tugas-tugas. Hal tersebut dilakukan sebagai sebuah stimulus bagi bawahannya untuk dapat mengembangkan potensi yang dimilikinya secara bebas dalam rangka mencapai visi dan misi pondok pesantren. Keempat, sebagai seorang pemimpin dan juga seorang kiai, kiai Buya Marwan Alwi Tuangku Lubuk Ameh mampu memberikan perhatiannya terhadap bawahannya baik secara individu maupun bersama-sama. Secara individu dilakukan oleh Buya Marwan Alwi Tuangku Lubuk Ameh melalui diskusi empat mata dan bertukar pikiran baik menyangkut persoalan pondok pesantren maupun persoalan pribadi. Sedangkan untuk memberi perhatian kepada semua anggota bawahannya Buya Marwan Alwi Tuangku Lubuk Ameh selalu mengadakan pertemuan di kediamannya setiap akhir bulan dan mengadakan acara yang melibatkan seluruh guru dan staf yang ada di Pondok Pesantren Darul Makmur Sungai Cubadak. Dengan beberapa perilaku kepemimpinan Buya Marwan Alwi Tuangku Lubuk Ameh tersebut ternyata mampu menjadikan Pondok Pesantren Darul Makmur berkembang cukup pesat dan cepat. Dengan perilaku tersebut dapat menumbuhkan semangat pada anggota bawahannya untuk tercapainya visi dan misi pondok pesantren, serta dapat mengembangkan organisasi lebih baik lagi.

Dalam upaya pengembangan sarana dan prasarana yang ada di Pondok Pesantren Darul Makmur, Buya Marwan Alwi Tuangku Lubuk Ameh mempunyai trik tersendiri dalam upaya menggalangan dana atau bantuan pengembangan. Melalui kharisma dan himbauan-himbauan yang beliau lakukan dalam berbagai kesempatan dan pertemuan, sehingga sumbangan terus mengalir dalam upaya percepatan pembangunan Pondok Pesantren Darul Makmur.

\section{Pendekatan Team Building di Pondok Pesantren Darul Makmur Sungai Cubadak}

Team building dapat dipahami sebagai proses yang terdiri dari kegiatan formal yang dimaksudkan untuk meningkatkan pengembangan dan fungsi tim kerja (Glinow, 2005). Jones (2013) menjelaskan bahwa salah satu bentuk team building adalah mengklarifikasi peran. Selama ini banyak orang beranggapan bahwa sebuah tim tidak ada bedanya dengan kelompok, padahal di antara kedua-nya memiliki perbedaan yang sangat signifikan. Dalam sebuah kelompok biasanya hubungan yang dibangun hanya sebatas berinteraksi untuk membagi informasi dan mengambil keputusan untuk membantu tiap anggota dalam bidang yang menjadi tanggungjawabnya. Sedangkan tim kerja merupakan kelompok yang upaya-upaya individunya menghasilkan suatu kinerja yang lebih besar dari-pada jumlah dari masukan-masukan individual (Fachry, 2015)

Kesalahan pandangan inilah yang kemudian berimplikasi terhadap kinerja tim dalam menjalankan tugas-tugasnya, sehingga tidak jarang masih banyak tim-tim yang dibangun tidak bisa menjelma menjadi sebuah tim yang solid karena dalam pelaksanaannya masih cenderung bersifat kelompok. Untuk mewujudkan team building yang kuat maka kiai Buya Marwan Alwi Tuangku Lubuk Ameh melakukan beberapa bentuk interaksi, diantaranya adalah: Pertama, dalam berinteraksi dengan para santri, kiai Buya Marwan Alwi Tuangku Lubuk Ameh menjadikan dirinya tidak hanya sebagai seorang guru, namun juga sebagai sosok ayah kepada anak-anaknya yang patut diteladani dan dijadikan panutan. Dalam hal ini kiai Buya Marwan Alwi Tuangku Lubuk Ameh melakukan interaksi fisik, yang artinya selalu menghadirkan dirinya ditengah-tengah para santri di setiap acara, serta memberikan peluang interaksi yang bersifat edukatif-demokratis selama 24 jam. Kebanyakan dalam berinteraksi dengan para santri, Buya Marwan Alwi Tuangku Lubuk Ameh lebih banyak memberikan motivasi melalui mauidhoh hasanah kepada mereka untuk selalu semangat dalam mencari ilmu di pondok pesantren. Selain itu kiai Buya Marwan Alwi Tuangku Lubuk Ameh juga menggunakan pendekatan motivasi penteladanan (uswah), misalnya memberikan contoh kepada santrinya dengan senantiasa shalat lima waktu berjamaah secara istiqamah (continual), sehingga dengan adanya 
1925 Kepemimpinan Buya Marwan Alwi Tuangku Lubuak Ameh, Pengembangan Organisasi, Team Building dan Prilaku Inovatif - Ridha Albiy, Muhammad Suhardi, Rusdinal, Nurhizrah Gistituati

DOI: https://doi.org/10.31004/edukatif.v3i5.691

interaksi yang akrab antara buya dengan santri, menunjukkan bahwa buya sebagai pengasuh pondok pesantren memberikan peluang untuk intensifikasi pendidikan.

Kedua, interaksi Buya Marwan Alwi Tuangku Lubuk Ameh dengan bawahannya yang dalam hal ini meliputi guru, asatidz, pengurus, serta staf dilakukan melalui interaksi pola pikir. Sebagai seorang pemimpin di Pondok Pesantren Darul Makmur, Buya Marwan Alwi Tuangku Lubuk Ameh tidak pernah mengabaikan saran dari bawahannya, sehingga dalam proses pelaksanaan program di Pondok Pesantren Darul Makmur, Buya Marwan Alwi Tuangku Lubuk Ameh selalu mengajak bawahannya untuk bertukar pikiran dan berdiskusi terlebih dahulu. Hal tersebut merupakan salah satu bangunan interaksi yang berkelanjutan dengan maksud agar mereka dapat merasa menjadi bagian dari pondok pesantren. Interaksi tersebut dilakukan setiap saat secara individu, karena Buya Marwan Alwi Tuangku Lubuk Ameh sendiri lebih suka diskusi secara empat mata, namun ada kalanya Buya Marwan Alwi Tuangku Lubuk Ameh berinteraksi dengan semua anggotanya yang dilakukan pada pertemuan rutin setiap akhir bulan untuk melakukan muhasabah dan juga pemberian motivasi.

Ketiga, selain melakukan interaksi dengan komunitas internal pondok pesantren, Buya Marwan Alwi Tuangku Lubuk Ameh juga melakukan interaksi dengan komunitas eksternal pondok pesantren yang dalam hal ini adalah masyarakat. Interaksi ruh yang dilakukan oleh Buya Marwan Alwi Tuangku Lubuk Ameh kepada masyarakat melalui kegiatan-kegiatan spiritual seperti: istighosah bersama, sholat hajat, tawajjuh, maupun acara keagamaan lainnya yang merupakan salah satu media buya untuk berinteraksi dengan masyarakat. Berbekal kedalaman ilmu agama yang diimbangi dengan pola hidup yang merakyat, serta kharisma yang tinggi dan selalu memberikan bantuan kepada orang yang membutuhkan, membuat masyarakat mendukung kegiatan spiritual yang diadakan oleh Buya Marwan Alwi Tuangku Lubuk Ameh.

\section{Pendekatan Perilaku Inovatif di Pondok Pesantren Darul Makmur Sungai Cubadak}

Perilaku inovatif berkaitan juga dengan inovasi-inovasi yang dilakukan oleh seorang pimpinan. Inovasi adalah salah satu kriteria yang membantu organisasi untuk menjadi berbeda di pasar dan memiliki keunggulan kompetitif, memenuhi harapan konsumen, menanggung persaingan tekanan (Sheeba \& Christopher, 2020). Kreativitas dalam pelatihan teknik membantu organisasi untuk menciptakan inovasi pada karyawan pada akhirnya mengarah pada organisasi inovatif.

Perilaku inovatif didefinisikan sebagai keseluruhan tindakan individu yang mengarah pada pemunculan, pengenalan dan penerapan dari sesuatu yang baru dan menguntungkan pada seluruh tingkat organisasi (Kresnandito, 2012). Perilaku inovatif juga salah satu faktor yang mempengaruhi kinerja (Leong \& Rasli, 2014), sehingga Buya Marwan Alwi Tuangku Lubuk Ameh dalam memimpin Pondok Pesantren Darul Makmur akan berupaya memecahkan permasalahan (mencari problem solving) dengan menggunakan cara yang berbeda dengan biasa orang lakukan tetapi akan menghasilkan efektif dan efisien. Perilaku inovatif yang dilakukan secara terstruktur dan sistematis membutuhkan komitmen, keterlibatan, dan kepemimpinan manajemen dalam mengembangkan faktor penunjang yang bersifat terknikal maupun non teknikal yang mampu mendorong perilaku inovatif dalam setiap peran pekerjaan. Dalam pemahaman praktis, perilaku kerja inovatif merupakan kontinum perilaku yang melibatkan proses berfikir kreatif (intrapersonal) hingga meyakinkan orang lain (interpersonal) dalam setiap pelaksanaan ide pada situasi pekerjaan (Jong \& Hartog, 2010).

Buya Marwan Alwi Tuangku Lubuk Ameh dalam memimpin Pondok Pesantren Darul Makmur tidak pernah memperlakukan dirinya sebagai pemimpin tunggal di pondok. Beliau menginginkan pondok ini menjadi organisasi yang demokratis, dalam artian Buya Marwan Alwi Tuangku Lubuk Ameh selalu memberikan kesempatan yang luas kepada para bawahannya untuk mengembangkan pondok ini sendiri sesuai dengan kemampuan yang mereka miliki. Dalam menggunakan pendekatan perilaku inovatif kiai $\mathrm{H}$. Achmad Zamachsyari selalu menggunakan cara dengan pendelegasian tugas-tugas, sehingga Buya Marwan Alwi 
1926 Kepemimpinan Buya Marwan Alwi Tuangku Lubuak Ameh, Pengembangan Organisasi, Team Building dan Prilaku Inovatif-Ridha Albiy, Muhammad Suhardi, Rusdinal, Nurhizrah Gistituati

DOI: https://doi.org/10.31004/edukatif.v3i5.691

Tuangku Lubuk Ameh hanya memberikan arahan bagaimana mereka harus bertindak sesuai dengan visi dan misi yang diharapkan bersama. Begitu juga dalam membuat suatu peraturan atau kebijakan Buya Marwan Alwi Tuangku Lubuk Ameh selalu melibatkan beberapa orang bawahannya. Namun dalam proses musyawarah Buya Marwan Alwi Tuangku Lubuk Ameh lebih sering diam karena ingin memberikan kesempatan kepada bawahannya untuk mengeluarkan ide-ide inovatif yang dipunya, sehingga Buya Marwan Alwi Tuangku Lubuk Ameh hanya berperan diakhir untuk menyetujui atau menolak hasil yang telah diskusikan secara bersama atau mufakat.

\section{KESIMPULAN}

Proses pengembangan organisasi di Pondok Pesantren Darul Makmur dilakukan melalui beberapa perilaku, yaitu: 1.) Buya Marwan Alwi Tuangku Lubuk Ameh mampu menjadikan dirinya sebagai sosok pemimpin yang deal di mata para bawahan melalui kharisma yang dimilikinya; 2.) Sebagai seorang pimpinan pondok pesantren, Buya Marwan Alwi Tuangku Lubuk Ameh piawai dalam memotivasi dan menginspirasi anggota bawahannya untuk memiliki semangat yang tinggi dalam mengembangkan pondok pesantren; 3 .) Buya Marwan Alwi Tuangku Lubuk Ameh tidak menjadikan dirinya sebagai seorang pemimpin tunggal yang otoriter terhadap bawahannya; dan 4.) Buya Marwan Alwi Tuangku Lubuk Ameh mampu memberikan perhatiannya terhadap bawahannya baik secara individu maupun bersama-sama. Proses pembentukan tim building di Pondok Pesantren Darul Makmur dilakukan melalui interaksi Buya Marwan Alwi Tuangku Lubuk Ameh dengan bawahannya yang dalam hal ini meliputi pimpinan pondok, kepala madrasah, guru, asatidz, pengurus, serta para staf dengan cara interaksi pola pikir. Hal tersebut merupakan salah satu bangunan interaksi yang berkelanjutan dengan maksud agar mereka dapat merasa menjadi bagian dari pondok pesantren. Proses menumbuhkan perilaku inovatif di Pondok Pesantren Darul Makmur Sungai Cubadak menggunakan cara dengan pendelegasian tugas-tugas, sehingga Buya Marwan Alwi Tuangku Lubuk Ameh hanya memberikan arahan bagaimana mereka harus bertindak sesuai dengan visi misi yang diharapkan bersama. Dari ketiga hal tersebut terlihat bahwa Buya Marwan Alwi Tuangku Lubuk Ameh menggabungkan gaya kepemimpinan transformasionalisme dengan gaya kepemimpinan demokratis dengan tetap berpegang prinsip pada al-Muhafadzatu 'ala qadimi as-salih wa al-akhdu bi al-jadidi al-aslah.

\section{DAFTAR PUSTAKA}

Ancok, D. (2012). Psikologi Kepemimpinan dan Inovasi. Erlangga.

Anwar, A. (2011). Pembaharuan pendidikan di Pesantren Lirboyo Kediri. Pustaka pelajar.

Banutu-Gomez, M. B., \& Banutu-Gomez, S. M. (2016). Organizational Change And Development. European Scientific Journal, ESJ, 12(22), 56. https://doi.org/10.19044/esj.2016.v12n22p56

Cummings, T. G. (2014). Organization Develeopment and Chaneg. Cengage Learning.

Fachry. (2015). Pengembangan Organisasi melalui Team Building, Kompetisi dan Kerjasama. 03(01).

Ghazali, B. (2002). Pesantren Berwawasan Lingkungan. CV. Prasasti.

Ghoni, D. (2012). Metode Penelitian Kualitatif (R. T. Sari (ed.)). ArRuzz Media.

Glinow, V. (2005). Organizational Behavior Organizational Behavior. NY : McGraw-HillIrwin.

Jong, J. De, \& Hartog, D. Den. (2010). Measuring Innovative Work Behavior. February. https://doi.org/10.1111/j.1467-8691.2010.00547.x

Kediri, L., \& Jombang, T. (n.d.). Kepemimpinan Kiai dalam Memelihara Budaya Organisasi. 8(1), 67-104. 
1927 Kepemimpinan Buya Marwan Alwi Tuangku Lubuak Ameh, Pengembangan Organisasi, Team Building dan Prilaku Inovatif - Ridha Albiy, Muhammad Suhardi, Rusdinal, Nurhizrah Gistituati

DOI: https://doi.org/10.31004/edukatif.v3i5.691

Kresnandito, A. P. (2012). Pengaruh Persepsi Kepemimpinan Transformasional terhadap Perilaku Inovatif Penyiar Radio. 1(02), 96-103.

Leong, C. T., \& Rasli, A. (2014). The Relationship between Innovative Work Behavior on Work Role Performance: An Empirical Study The Relationship between innovative work behavior on work role performance: An empirical study. Procedia - Social and Behavioral Sciences, 129(May), 592-600. https://doi.org/10.1016/j.sbspro.2014.03.717

Robbins, Stephen P, T. A. dan J. (2014). Perilaku Organisasi (Organizational Behavior) (12th ed.). Salemba Empat.

Saefullah, U. (2012). Manajemen Pendidikan islam. CV. Pustaka Setia.

Sheeba, M. J., \& Christopher, P. B. (2020). Exploring the role of training and development in creating innovative work behaviors and accomplishing non-routine cognitive jobs for organizational effectiveness. Journal of Critical Reviews, 7(4), 263-267. https://doi.org/10.31838/jcr.07.04.49

Siagian, S. P. (2010). Teori dan Praktek Kepemimpinan. Rineka Cipta.

Siswanto, S. (2015). Desain mutu pendidikan pesantren. KARSA: Journal of Social and Islamic Culture, 23(2), 258-274. https://doi.org/10.19105/karsa.v2312.726

Solomon, A., \& Steyn, R. (2017). Leadership style and leadership effectiveness: Does cultural intelligence moderate the relationship? Acta Commercii, 17(1), 1-13. https://doi.org/10.4102/ac.v17i1.453

Suharto, H. B. (2011). Dari Pesantren Untuk Umat. Imtiyaz.

Wijaya, H. (2014). Analisis Data Kualitatif Model Spradley ( Etnografi ). 283-284.

Wirawan. (2013). Kepemimpinan:Teori,Psikologi, Perilaku Organisasi,Aplikasi dan Penelitian / Wirawan (pertaman). Grafindo Persada.

Zamakhsyarie, D. (2011). Tradisi Pesantren Studi Pandangan Hidup Kyai dan Visinya Mengenai Masa Depan Indonesia (10th ed.). LP3ES.

Zein, Z., \& Salam, A. (2019). IMPLEMENTASI KHAZANAH SURAU TERHADAP PENDIDIKAN ISLAM MODERN. 6(2), 127-141. https://doi.org/10.17509/t.v6i2. 